\title{
Sixteenth-Century Greek Editions at Iowa
}

\author{
DONALD F. JACKSON
}

The printing of Greek authors began late in the fifteenth century. The West had completely lost contact with this half of the GrecoRoman tradition by the fourteenth century, but the importation of the first Greek teacher of the Renaissance, Manuel Chrysoloras, from the East in 1397 permitted a few Florentines to become familiar with Hellenic literature again. This group hosted the Orthodox hierarchy at the Union Council in the second quarter of the fifteenth century and thereby opened new horizons in Greek literature for itself. The Turkish threat to Constantinople which prompted the Council soon sent great numbers of Greeks westward. By the time the city fell (1453) sizeable Greek colonies were established in most Italian urban areas. The largest by far was in Venice, which had itself maintained a colony of several thousand persons in Constantinople for many years. The Greeks apparently felt most comfortable among "Franks" they knew.

These expatriates generally supported themselves by instructing young Italians in the Greek language and by scribal work for Italian bibliophiles. Their common interests led to the establishment of academies and, again, the most outstanding was located in Venice. Its founder was Aldus Manutius, a Roman who had set up a press at Venice in 1490 . He wished to enjoy the relative security from political strife available there and to avail himself of the wealth of scholarly talent in Venice and at the university in Padua. In the next twenty-five years the Aldine Academy numbered among its members, at one time or another, most of the great Greek teachers of the period and most of the learned Italian hellenophiles. It even attracted scholars from northern Europe, including Erasmus of Rotterdam.

Aldus learned Greek while living with Pico della Mirandola in 1482 , later being entrusted with the education of his nephew, Alberto 
Pio of Carpi. His great desire was, however, to alleviate the shortage of Greek texts by printing inexpensive octavo-size volumes in a readable form. The italic type he developed is still the basis for continental European printing in Greek. Soon after joining the printers' fraternity, Aldus followed tradition by marrying into a printing family. His wife was the daughter of Andreas Torresanus de Asola, who had studied at and taken over Nicholas Jenson's press in Venice. In 1508 Aldus and his father-in-law formed a partnership which lasted until Manutius' death in 1514.

Our earliest Aldine text is the 1502 Sophocles. ${ }^{1}$ The volume, a first edition (editio princeps), is dedicated to the great Greek scholar and politician Janus Lascaris as a product of the Neacademia of Aldus. Although the title page lists the scholia as part of the publication, they did not appear until 1518 at Rome edited by Lascaris. The text of the tragedies is based on the work of the Byzantine grammarian, Manuel Moschopoulos. Adrian Turnebus later published a text based on that of Demetrius Triclinius. These two editions were used as bases for later texts for centuries. At the time, bibliophiles who refused to have printed books in their libraries often had manuscripts copied from Aldus' edition. Publication of tragedies continued in the following year with the plays of Euripides. ${ }^{2}$ Lascaris had edited four plays which were published at Florence in 1496. The Aldine is, however, the editio princeps of the whole corpus. An edition of the Greek Anthology appeared in this year as well, ${ }^{3}$ based on Lascaris' edition of 1494. Aldus' Homer of 1504 is dedicated to Jerome Aleander, who belonged to the New Academy and became a teacher of Greek at Paris soon after. ${ }^{4}$ Homer had previously been edited by Demetrius Chalcondyles, to whom Aldus dedicated the Euripides of 1503.

A war between Venice and the League of Cambrai forced Aldus to cease publication through 1510 and 1511 . He took refuge at Ferrara beside Lucretia Borgia before returning home. From the postwar period we have his 1513 Pindar. ${ }^{5}$ The volume also contains Dionysius Periegetes, Lycophron (all three being editiones principes) and the

1 Sophoclis tragaediae septem cum commentariis. Venice: Aldus, 1502. This volume and the forty-five following cited in the footmotes at present comprise the collection of sixteenth-century editions of ancient Greek authors owned by The University of Iowa Libraries.

2 Euripidis tragoediae septendecim. Venice: Aldus, 1503.

3 Florilegium diversorum epigrammatum in septem libros. Venice: Aldus, 1503.

4 Homeri llias. Ulyssea, batrachomyomachia, hymni XXXII. [Venice] Aldus [1504].

5 Pindari Olympia, Pythia, Nemea, Isthmia. Callimachi hymni qui inveniuntur. Dionysii de situ orbis. Lycophronis Alexandra. Venice: Aldus-Asulanus, 1513.

[4]. 
hymns of Callimachus (printed at Florence in 1494 with Lascaris again as editor).

A few days before his death Aldus published the Suda Lexicon, an enlarged version of the 1499 Milanese editio princeps. ${ }^{6}$ Both the press and Aldus' three-year-old son Paul were now placed in the care of Andreas d'Asola, who religiously followed the guiding principles of his son-in-law until his own death in 1529. From the 1514-1529 period of the Aldine press we have a handbook-size edition of Herodian based on the large folio editio princeps printed by Aldus in 1502.7 The 1534 first edition of the speeches of Themistius, ${ }^{8}$ edited by Victor Trincavelli, cites the loss of Aldus and d'Asola as well as the rejuvenation of the press under the younger generation. Italy and the world had nonetheless lost one of the founding fathers of Greek printing and a great scholar and organizer of scholars at the same time. Aldus' name is still unsurpassed as a publisher of learned Greek texts.

Other Venetian editions in our library include Aristotle's Rhetoric ${ }^{9}$ and the comedies of Aristophanes by Bartolomeo Zanetti. ${ }^{10}$ Zanetti was a wandering printer from Brescia. He was associated for a time with Filippo di Giunta, who began publishing at Florence in 1497. Giunta's first productions were Greek. He imitated Aldus' italics and format, even basing some of his texts on earlier Aldine editions. We have the 1516 "Junta" editio princeps of the corpus of Xenophon's works. ${ }^{11}$ The actual type used by Filippo di Giunta had formerly belonged to the Cretan expatriate Zachary Callierges. He had run the first all-Greek press at Venice (1499-1500), which was dissolved because of internal strife. A later foundation at Rome, under the impetus of Hellenic studies at the court of the Medici Pope Leo X, was more auspicious. Rome had not produced a single Greek text before Callierges' arrival. We have his 1516 edition of Theocritus, the second Greek book printed at Rome. ${ }^{12}$

Under the influence of northern scholars imbued with the new learning encountered in Italy, Greek presses appeared in Germany

${ }^{6}$ Suida. Venice: Aldus-Asulanus, 1514.

7 Herodiani historiarum libri VIII. Venice: Aldus-Asulanus, 1524.

8 Omnia Themistii opera. Alexandri Aphrodisiensis libri duo de anima et de fato unus. Venice: Heirs of Aldus-Asulanus, 1534.

9 Aristotelis de arte rhetorica libri tres. Ad Alexandrum rhetorica. De poetica. Venice: Zanetti, 1536.

10 Aristophanis facetissimi comoediae undecim. Venice: Zanetti, 1538.

11 Xenophontis Cyri pedias, anabaseos, apomnemoneumaton, venatoria, de re equestri, de equis alendis, Lacedaemonorum resp., Atheniensium resp., oeconomica, Hieron, symposium, de Graecorum gestis. Florence: Junta, 1516.

12 Theocritou eidyllia hex \& triaconta. Scholia. Rome: Callierges, 1516. 
and France early in the sixteenth century. The most distinguished of these was that of the Estienne family in Paris. Founded by Henry Estienne, the press of the Stephani, as the name appears in its Hellenized form, presented its first Greek publication in 1544. The volume was the Ecclesiastical History of Eusebius Pamphilus published by Henry's son Robert. ${ }^{13}$ King Francis I, then in the process of gathering manuscripts from Greece and Italy for his library at Fontainebleau, wished the benefits of the collection to be available to his subjects. He had therefore allocated funds in 1541 for a new and exquisite font of Greek type to be cut by Claude Garamond. Based on the handwriting of the Cretan scribe Angelo Vergecio, at the time King's Librarian at Fontainebleau, the font was delivered to Robert Stephanus. As King's Printer in Greek (typographus regius) he used the Garamond type for the first time in the Eusebius text, which served as a standard of that author for a century. The manuscripts upon which the text was based, along with the others then situated at Fontainebleau, went later to Paris, where they serve as the foundation for today's great collection in the Bibliothèque National. Because Francis was especially fond of historical works, Robert printed ten books of Roman Antiquities by Dionysius of Halicarnassus for him in 1546. ${ }^{14}$ Both the Dionysius and Eusebius are editiones principes.

Robert Stephanus became involved in disputes with the Faculty of Theology at Paris over his interpretation of passages in biblical texts and his printing of unacceptable variant readings. To the Faculty these smacked of heretical teaching. With the death of his patron Francis, Robert secretly made copies of the royal type and smuggled them off to Geneva. He followed them and set up shop there in 1550. The editio princeps of Appian's Roman History, ${ }^{15}$ which he had begun, was completed and published by his brother Charles, who remained behind in Paris. Robert now fully embraced Protestantism and devoted his time, almost completely, to publishing religious works, many for John Calvin, who was his friend and associate in Geneva. He died in 1559, one of the most-respected publishers of scholarly editions in all of Europe and a first-rate scholar in Greek. Latin, and Hebrew.

The entire Stephanus press passed to Robert's son Henry, although

13 Ecclesiasticae historiae Eusebii Pamphili (eiusdem de vita Constantini), Socratis, Theodoriti episcopi Cyrensis, collectaneorum ex historia eccles. Theodori Lectoris, Hermii Sozomeni, Evagrii. Paris: R. Stephanus, 1544.

14 Dionysii Halicarnassei antiquitatum Romanarum libri X. Paris: R. Stephanus, 1546.

15 Appiani Alexandrini Romanarum historiarum. Paris: C. Stephanus, 1551. 
he was only one of three surviving sons. The others, Robert and Charles, had returned to Paris by 1559 and had rejoined the Catholic Church, much to their father's consternation. Henry had worked closely with his father in the preparation of classical texts during the last five years of the latter's life. In 1557 he published his first independent works, among them the editio princeps of the Greek historians and geographers ${ }^{16}$ and the tragedies of Aeschylus. ${ }^{17}$ Henry edited the first himself. The second was edited by Petrus Victorius and featured the first appearance of the Agamemnon in print. Although Henry styled himself in 1557 a "Parisian printer" (ex officina IIenrici Stephani Parisiensis typographi), the paper of the historical volume has been recognized as Swiss. It was undoubtedly printed at his father's shop in Geneva. A possible explanation for the Parisian designation is that his first publication was printed in Paris with the royal type then in the possession of Guillaume Morel. This one publication might have been enough to have linked Henry's name with Paris and to have warranted the misleading designation. The joint publication with Morel, Anacreon's Odes, ${ }^{18}$ includes a translation of the poems by his brother Robert. The younger Estiennes evidently got along with one another better than they did with the older generation.

By 1559 Henry had cut his Parisian ties, and in his edition of Diodorus Siculus' Histories he called himself "Printer to Ulrich Fugger."19 This work had been initiated by his father as part of the historical series for Francis I. Diodorus had appeared elsewhere in 1539, but in only a five-book edition. Henry's included ten additional books which he had discovered at Rome in 1554. Fugger was still his patron in 1562 when his Orations of Themistius appeared ${ }^{20}$ and in 1564 when he published the Histories of Thucydides dedicated to Joachim Camerarius. ${ }^{21}$ Of the fourteen speeches in the Themistius volume, the last six had not been printed before. Fugger (1526-1584) was a Protestant fugitive from an enormously wealthy Catholic family in Augsburg. He collected Greek manuscripts in great numbers and bequeathed them to the university at Heidelberg in the Palatinate, the

16 Ex Ctesia, Agatharchide, Memnone excerptae historiae. Appiani Iberica. Item, de gestis Annibalis. [Geneva] H. Stephanus, 1557.

17 Aeschyli tragoediae VII. [Geneva] H. Stephanus, 1557.

18 Anacreontis et aliorum lyricorum aliquot poetarum odae. Paris: G. Morel-H. Stephanus, 1556.

19 Diodori Siculi bibliothecae historicae libri XV. [Geneva] H. Stephanus, 1559.

20 Themistii Philosophi orationes XIIII. [Geneva] H. Stephanus, 1562.

21 Thucydidis Olori filii de bello Peloponnesiaco libri VIII. [Geneva] H. Stephanus, 1564. 
land of his exile. Camerarius (1500-1574), an associate of Melanchthon, helped to reorganize the universities at Tübingen and Leipzig, and as a leading Protestant reformer corresponded with Francis I about a reconciliation with Catholicism. As a scholar he translated several Greek authors into Latin, among them the historians, making this dedication quite apropos. Clearly, under Henry the Stephanus press continued its traditional ties with the leaders of Protestantism and classical studies.

In 1568 Henry published his edition of Sophocles as a continuation of the tragic series begun with Aeschylus eleven years before. ${ }^{22} \mathrm{He}$ included notes and translations by Camerarius. The great threevolume edition of Plato appeared in $1578 .{ }^{23}$ Realizing the epic quality of the work, he dedicated the first volume to Queen Elizabeth, the second to James VI of Scotland, and the third to the Republic of Bern. This remained the pre-eminent Plato text for two centuries. References to Plato still today cite the pagination of the Stephanus edition. The two last products of Henry's press in our library are histories. Herodian and Zosimus, the latter printed for the first time, appeared in 1581.24 Angelo Poliziano's Latin translation faces the Greek text. Henry published a second, corrected and enlarged edition of Thucydides in $1588 .{ }^{25}$ As in the earlier edition, a Latin translation by Lorenzo Valla is included.

When Robert Estienne fled to Geneva in 1550, the new king of France, Henry II, was left without a printer in Greek. The position had become quite prestigious under Robert's scholarly hand. Henry therefore chose a man who outshone even the Stephani in learning, Adrien Turnèbe (Turnebus), who had held the chair of Greek and Latin literature at the Collège Royal since 1547. Turnebus had no experience as a printer and also had some difficulty in extricating the royal type from Robert's brother Charles. Nonetheless, in 1552 he published the editio princeps of all the works of Philo Judaeus then known. ${ }^{26}$ This was followed by the tragedies of Sophocles, ${ }^{27}$ acknowledged for its excellence by Henry Estienne in his own 1568 edition, and the first edition of Homer's Iliad to be based on sound critical

22 Sophoclis tragoediae septem una cum omnibus Graecis scholiis et cum Latinis Ioach. Camerarii. [Geneva] H. Stephanus, 1568.

23 Platonis opera quae extant omnia. [Geneva] H. Stephanus, 1578.

24 Herodiani historiarum libri VIII. Zasimi historiarum libri II. [Geneva] H. Stephanus, 1581.

25 Thucydidis de bello Peloponnesiaco libri VIII. [Geneva] H. Stephanus, 1588.

26 Philonis Judaei in libros Mosis, de mundi opificio, historicos, de legibus, eiusdem libri singulares. Paris: Turnebus, 1552.

27 Sophoclis tragoediae. Paris: Turnebus, 1553. 
investigation. ${ }^{28}$ Obviously uncomfortable in his strange position, Turnebus handed the office of King's Printer in Greek over to his disciple Guillaume Morel in 1555, the same Morelius who shared publication of the poems of Anacreon with Robert Estienne's sons in 1556. Morel had set up his own shop in $\mathbf{1 5 4 9}$ and almost immediately gained fame with a very successful series of Greek editions. As Turnebus' successor he published Nicander's Theriaca in 1557 with a facing Latin translation. ${ }^{29}$ Ancient scholia and his own notes were appended. Another Paris publisher of this period, famed for execution of the printer's art if not for knowledgeable editing, was Michel Vascosan (Vascosanus). His and Robert Estienne's wives were sisters. Their father was Josse Badius, a pioneer among Paris printers. Vascosanus was named Ordinary King's Printer in 1561 and held the position for fifteen years. We have one of his early publications, an introduction to Plato by Alcinous, now attributed to Albinus. ${ }^{30}$ Although dated 1550 , the Greek text appears to be a separate production of 1532 , preceded by a later Latin translation, the two being bound together. The famed Marsilio Ficino's translations of Speusippus' De Platonis definitionibus and Xenocrates' De morte are also included.

A neighbor of Robert Estienne, Christian Wechel, opened a press at Paris around 1526. His son Andreas, who took over the business in 1554, published the first edition of the emperor Julian's Misopogon together with his letters in $1566 .{ }^{31}$ Six years later Andreas, as Estienne had before him, moved his press out of Paris (to Frankfurt-amMain) because of religious intolerance.

These problems of the Parisian press with the Faculty of Theology, and the failure of the French throne to support its printers impartially, allowed the momentum of learned publication in northern Europe to pass from the City of Light back to German-speaking areas from which it had been wrested in the second quarter of the sixteenth century. Geneva became illustrious under the Stephani, but Basle had long been the site of an energetic scholarly press.

German-speaking scholars had been much more intimately involved in the beginnings of Italian printing and in the study of the Greek classics than the French. It is not surprising, therefore, that great advances were made in German and Swiss printing of Greek before Robert Estienne made Paris northern Europe's center for such publi-

\footnotetext{
28 Homent llias. Paris: Turnebus, 1554.

29 Nicandri theriaca. Paris: Morelius, 1557.

30 Alcinoi philosophi Platonici de doctrina Platonis liber. Paris: Vascosanus,
} 1550 .

31 Juliani imperatoris misopogon et epistulae. Paris: A. Wechel, 1566. 
cation. Erasmus of Rotterdam, while teaching at the University of Basle, edited the first Greek book published in that city (1516), the New Testament. ${ }^{32}$ Erasmus had the assistance of his good friend Johann Froben in winning a race with the Spanish Cardinal Ximinez to present the world with the first Greek edition of the work. The Spanish polyglot Bible appeared in the following year. Froben had begun printing at Basle in 1491 and, with the presence of Erasmus, his workshop was one of the most important centers of German humanism until his death in 1527 .

Froben's widow married Johann Herwagen (Hervagius) who had printed at Strassburg until 1528. After a short partnership with his stepson Hieronymus, he published independently at Basle. One of his first independent works was the Demosthenes of $1532 .{ }^{33}$ Erasmus wrote the dedicatory Preface and Johann Oporinus added a note to the reader. The romance of Heliodorus was published for the first time by Herwagen in $1534 .{ }^{34}$ It was unknown in modern times until its discovery among the manuscripts of Matthias Corvinus, king of Hungary, during the sack of Buda in 1526. Our copy bears Herwagen's handwritten dedication to Janus Cornatius (Frankfurt 1535).

Printers at Basle often collaborated. Herwagen in 1538 worked with Andreas Hartmann (Karthander=Cratander) and Johann Bebel in publishing an edition of Galen. We have Plutarch's Parallel Lives printed by Hartmann and Bebel. ${ }^{35}$ Simon Grynaeus dedicated this work to Johann Oporinus. The latter was a professor of Greek at Basle from 1538 and opened his own printing shop in 1544 . He remained basically a scholar, however, printing fine editions while making little profit. His 1549 Stobaeus $^{36}$ is a reissue of an earlier publication from his shop, as is the Sibylline Oracles of $1555 . .^{37}$ In the following year he published a volume of Dionysius Periegetes. ${ }^{38}$ Oporinus published so frequently, in fact, that he often had to employ the facilities of

32 Novum instrumentum. Basle: Froben, 1516. Our library has the second volume.

33 Demosthenis Graecorum oratorum omnium facile principis orationes duas et sexaginta. Basle: Hervagius, 1532.

34 Heliodori historiae Aethiopicae. Basle: Hervagius, 1534.

35 Plutarchi quae vocantur parallela. Basle: Cratander-Bebel, 1533.

36 Ioannis Stobaei sententie ex thesauris Graecorum delectae. Basle: Oporinus, 1549.

37 Sibyllinorum oraculorum libri VIII. Basle: Oporinus, 1555. A similar volume (Sibyllina oracula. Paris: Obsopoeus 1599) is also contained in our collection. From the same year we have a related work, Hori Apollinis selecta hieroglyphica. Rome: Zanetti, 1599.

38 Dionysii Alexandrini de situ orbis. Basle: Oporinus, 1556. 
printers from other cities. Such fervid activity of native printers and the constant arrival of fugitive printers from other countries made Germany and Switzerland the leading publishers of Greek texts in the second half of the fifteenth century. Before retiring in 1567 Oporinus published an edition of Lycophron with translations by William Canter and Joseph Scaliger. ${ }^{39}$ Oporinus shared the labor with Peter Perna, an Italian from Lucca who studied at Basle and began printing there in 1538 . We possess one last product of Basle which is rather mysterious. The title page bears the word "Basileae," but the dedication by Johann Birchmann is dated "Cologne, 1542." No publisher is mentioned. ${ }^{40}$

A very active Greek press operated in Heidelberg late in the fifteenth century, largely due to the arrival of the fugitive French Calvinist, Hieronymus Commelinus. Having formerly studied at Heidelberg, Commelinus fled Lyons and began printing in Germany in 1587. Closely allied with the scholar Friedrich Sylburg, he published a series of fine classical editions before his death in 1597 . We have his Etymologicum Magnum of 1594, edited by Sylburg. ${ }^{41}$ His Lycophron of 1596 is a copy of the 1566 Oporinus-Perna edition, lacking only Scaliger's translation. ${ }^{42}$ Commelinus' heirs published the editio princeps of Iamblichus' Life of Pythagoras in his name, although the actual printing was done by Aegidius Radaeus. ${ }^{43}$ The Athenaeus of the same year also bears Commelinus' name, but was printed at Lyons by Guichardus Iullieron. ${ }^{44}$

With the death of Commelinus we come to the end of the period embraced by this article. The sixteenth century had nurtured the seed planted during the Italian Renaissance and saw it branch out into all the nations of northern Europe. There the proximity of Greek learning to the origins of Christianity and its inevitable clash with doctrine based solely on a Latin tradition prompted dissident spirits, especially in France, to attempt to stifle the growth rather than to prune and tend it toward healthy fruition. It thrived in Germany, however, as later in Holland and England, drawing along with itself the centers of

39 Lycophronis Chalcidensis Alexandrae. Basle: Oporinus-Perna, 1566.

40 Hesiodi Ascraei poetae vetustissimi ac sapientissimi opera, quae quidem extant, omnia Graece. Basle [1542].

41 Etymologicon magnum. [Heidelberg] Commelinus, 1594.

42 Lycophronis Chalcidensis Alexandra, sive Cassandra. [Heidelberg] Commelinus, 1596.

43 Iamblichi Chalcidensis ex Syria coele de vita Pythagorae et protrepticae orationes ad philosophiam lib. II. [Heidelberg] Commelinus, 1598.

44 Athenaei deipnosophistarum libri XV. [Heidelberg] Commelinus, 1598. 
humanistic endeavor. All of this growth, development, vicissitude, and movement are well represented by the Greek volumes now in The University of Iowa Libraries, a collection which is continually expanding in one of the most important areas in the history of western thought. 